\title{
EFFECT OF CHICKPEA (Cicer arietinum L.) GERMINATION ON THE MAJOR GLOBULIN CONTENT AND IN VITRO DIGESTIBILITY ${ }^{1}$
}

\author{
Guilherme Vanucchi PORTARI ${ }^{2}$, Olga Luisa TAVANO², Maraiza A. da SILVA², Valdir Augusto NEVES ${ }^{2, *}$
}

\section{SUMMARY}

Chickpea seed germination was carried out over a period of 6 days. Little variation in the nitrogen and total globulin content was observed. The major globulin (11 S type) showed higher variation after the $4^{\text {th }}$ day of germination. The elution behaviour and distribution of the isolated major globulin fraction on Sepharose CL-6B chromatography showed little modification at the end of germination. On SDS-PAGE the peak eluted from Sepharose CL-6B showed changes in protein bands between 20 and $30 \mathrm{kDa}$ and above $60 \mathrm{kDa}$, indicating protein degradation during the period. Proteolytic activity was detected in the albumin fraction of the seeds, which increased up to the fourth and then decreased up to the sixth day, when isolated chickpea total globulin and casein were used as substrates. Chickpea flour, isolated albumin and total globulin fractions did not show an increase for in vitro digestibility; however, the isolated major globulin was more susceptible to hydrolysis after germination.

Keywords: chickpea germination, protein fractions, major globulin, protease activity, in vitro digestibility.

\section{RESUMO}

EFEITO DA GERMINAÇÃO DE GRÃO-DE-BICO (Cicer arietinum L.) NA GLOBULINA MAJORITÁRIA E DIGESTIBILIDADE IN VITRO. A germinação das sementes de grão-de-bico foi acompanhada por um período de 6 dias, no qual pequenas variações nos teores de nitrogênio e globulina total foram registradas. A globulina majoritária (tipo $11 \mathrm{~S}$ ) apresentou maiores variações após o quarto dia de germinação. A natureza e distribuição da fração globulina majoritária isolada na cromatografia em Sepharose CL-6B mostrou pequenas modificações ao final do período de germinação. A eletroforese em gel de poliacrilamida com dodecilssulfato de sódio do pico eluído na cromatografia em Sepharose CL-6B demonstra modificações nas bandas de proteínas entre os pesos moleculares de 20 e $30 \mathrm{kDa}$ e acima de $60 \mathrm{kDa}$, indicando degradação protéica durante o período. Atividade proteolítica foi detectada na fração albumina da semente que aumentou até o quarto dia, seguido de queda até o sexto dia de germinação, quando da utilização de globulina total isolada da semente e caseína como substratos. Farinha de grão-de-bico, frações albumina e globulina total isoladas não apresentaram aumento na digestibilidade in vitro; entretanto, a fração globulina majoritária isolada foi mais suscetível à hidrólise após germinação.

Palavras-chave: germinação, frações protéicas, globulina majoritária, atividade proteolítica, digestibilidade in vitro.

\section{1 - INTRODUCTION}

Legume seeds are an important protein source for human consumption in developing countries. The qualitative and quantitative composition of the protein is one of the basic factors to select plants for nutritive value, and since globulins are the major proteins in legumes, there have been too many studies about their characterization in various species [9]. Different factors appear to contribute to the poor nutritive value of legume proteins such as the presence of antinutrients, amino acid composition and digestibility $[6,7,19]$. The digestibility of legume proteins is relatively low due to the presence of antiphysiological factors and structural characteristics of the storage proteins $[6,11]$. In this respect, the enzymatic susceptibility of the protein fractions appears to be important, since protein associations, a common fact in legume protein systems, also affect proteolysis. A considerable variation has been reported for chickpea protein digestibility in the literature $[7,22,31]$. However, contrary to other species such as beans and soybeans, little is known about the role of chickpea protein fractions.

${ }^{1}$ Recebido para publicação em 14/04/2005. Aceito para publicação em 06/09/2005 (001511).

${ }^{2}$ Departamento de Alimentos e Nutrição. Faculdade de Ciências Farmacêuticas - Universidade Paulista Julio de Mesquita Filho-UNESP. Rodovia Araraquara-Jaú km 1. CEP: 14801-902 - Araraquara - S.P. E-mail: nevesva@fcfar.unesp.br.

*A quem a correspondência deve ser enviada.
Protein characteristics and its mobilization during seed germination have been extensively studied in some species $[1,4,6,11,25,29]$, indicating a slow hydrolysis, whose mechanism of degradation control is still uncertain. In addition, germination induces changes in protein $[22,23]$ and starch digestibility, which probably also result from enzymatic action. GANESH KUMAR \& VENKATARAMAN [12] and AHMED et al. [1] observed alterations in the protein patterns of some legume seeds during germination using ultrafiltration and PAGE (polyacrylamide gel electrophoresis) and suggested that the changes were legume species dependent. CHAVAN et al. [7] were emphatic about the absence of investigations about the mobilization and characteristics of the different protein fractions from the cotyledons of chickpea seeds during germination.

We report here the alterations of storage protein fractions from chickpea after their characterization by chromatography and polyacrylamide gel electrophoresis and the determination of in vitro digestibility (IVPD) during seed germination.

\section{2 - MATERIAL AND METHODS}

\section{1 - Material}

Chickpea (Cicer arietinum L.), cv IAC-Marrocos were purchased from Instituto Agronômico de Campinas, Campinas, São Paulo, Brazil. 


\subsection{1 - Germination}

Chickpea seeds were washed with water, soaked in distilled water and immersed for one minute in a solution containing $0.001 \%$ Benlate (methyl-1-butyl carbamoyl-2benzimidazole carbamate). Next, the seeds were drained and wrapped in appropriate paper (germitest paper) previously treated with Benlate solution. Germination was carried out in a germination chamber with enough moisture at a temperature of $16-18^{\circ} \mathrm{C}$ in the dark. Only distilled water was sprayed daily during germination period. Cotyledons were obtained from seeds at $0,2,4$ and 6 days germinating for protein studies. At the same germination times, sprouts were separated from the seeds. The seeds were manually dehulled; the air-dried cotyledons were ground to pass through a 60-mesh sieve, defatted in n-hexane ( $1: 8)$, filtered and dried at room temperature. The deffated flours obtained were used for total and non-protein nitrogen determinations, for protein fractions isolation and for others analyses. All chemicals used were reagents grade.

\section{2 - Methods}

\subsection{1 - Nitrogen determination}

Total nitrogen and protein nitrogen (TCA-precipitable) were estimated by the microkjeldhal method [5]. The non-protein nitrogen was extracted from the flour with $10 \%$ trichloroacetic acid (TCA), homogenized in a magnetic stirrer for 1 $\mathrm{h}$ at room temperature, and centrifuged ( $15000 \mathrm{~g} / 40 \mathrm{~min}$ ). The residue was reextracted (2X), the supernatants were combined and $\mathrm{N}$ determined as described above.

\subsection{2 - Protein fractionation}

Protein fractions were successively extracted from defatted chickpea flour on each germination day $(0,2$, 4, 6 days) ( $1: 10$ flour to solvent ratio) with deionized water and $0.5 \mathrm{M} \mathrm{NaCl}$ solution as described by SATHE $\&$ SALUNKHE [28]. The residue remaining after $\mathrm{NaCl}$ extraction was successively extracted with $70 \%$ ethanol and $0.1 \mathrm{~N} \mathrm{NaOH}$ to separate the prolamin and glutelin fractions, respectively. The albumins and total globulins were resuspended in distilled water and lyophilized. The lyophilized protein fractions from the ungerminated and germinated seeds were submitted to nitrogen content determination in triplicate.

The chickpea major globulin from each germination time was obtained by the procedure described by GANESH KUMAR, VENTAKARAMAN and APPU RAO [14].

\subsection{3 - Gel chromatography}

Aliquots (40-60 mg) of lyophilized total and major globulins isolated from ungerminated and germinated seed flours were solubilized in $5 \mathrm{mM}$ KPi-buffer, $\mathrm{pH} 7.5$ with $0.5 \mathrm{M}$ $\mathrm{NaCl}$ and separately applied to a column packed with Sepharose CL-6B resin $(2.5 \times 100 \mathrm{~cm})$, equilibrated with the same buffer. Fractions of $5.5 \mathrm{ml}$ were collected with a
FRAC-100 fraction collector and the protein was monitored by UV $280 \mathrm{~nm}$. The void volume (Vo) of the column was determined by the elution of Blue dextran 2000.

\subsection{4 - Protein determination}

Proteins were determined by the method of LOWRY et al. [21], using bovine serum albumin as a standard. In the extraction procedures was used the nitrogen content multiplied by the 6.25 factor. Absorbance at $280 \mathrm{~nm}$ was also used to monitor protein in the column eluates.

\subsection{5 - Sodium dodecylsulfate polyacrylamide gel electrophoresis (SDS-PAGE)}

SDS-PAGE was carried out by the method of LAEMLLI [20], with $12.5 \%$ monomer concentration. The MW markers employed were: cytochrome C (12.4 kDa), soybean trypsin inhibitor (21.5 kDa), carbonic anhydrase (29 kDa), ovalbumin ( $45 \mathrm{kDa})$, and bovine serum albumin ( $67 \mathrm{kDa})$. Relative mobility was determined by the migration of the bromophenol marker dye.

\subsection{6 - Proteolytic activity determination}

The presence of proteases in the protein extracts and the isolated fractions, germinated and ungerminated, was verified by measuring the hydrolysis grade using $1 \%$ casein as substrate. The proteolytic activity was determined using the albumin fraction for ungerminated and germinated seeds, as the enzyme source. Aliquots were prepared in triplicate for: solution of enzyme: casein, casein whitout enzyme and only enzyme, followed by incubation of tubes sealed with parafilm in a water bath at $37^{\circ} \mathrm{C}$ in a buffer (KPi-citrate, pH 5.5) mixture. The reactions were initiated by the enzyme addition (albumin fraction) and interrupted at different times of incubation $(0,30,60,90,120 \mathrm{e}$ $240 \mathrm{~min}$ ). The tubes were removed from the bath, and the contents were diluted with cold distilled water (10X) and immediately utilized for amino nitrogen determination according to the method of SPADARO et al. [30] using L-leucine as a standard. The results were expressed as $\mu \mathrm{g}$ amino acid/mg protein in the assay after 4 hours reaction for each germination time. All hydrolysis assays were performed in triplicate with casein and isolated total globulin as substrates.

\subsection{7 - In vitro digestibility}

The in vitro protein digestibility of the flour and all protein fractions (raw and heated at $121.1^{\circ} \mathrm{C} / 15 \mathrm{~min}$ ) was determined by the procedure described by AKESON \& STAHMAN [3] using the pepsin and pancreatin sequence after incubation at $37^{\circ} \mathrm{C}$ for 3 and $24 \mathrm{~h}$, respectively. The enzymatic reaction was interrupted by the addition of $10 \%$ TCA, followed by centrifugation and the supernatant used to determine the amino nitrogen. The extent of hydrolysis was determined by the increase of free amino groups using 2, 4, 6 -trinitrobenzenesulphonic acid (TNBS) according to the method of SPADARO et al. [30]. The percentage of total amino groups was calculated using leucine as a standard 
and the results are expressed in relation to casein (Hammarsteen) considered as totally digested (100\%). All in vitro protein assays were performed in triplicate.

\section{3 - RESULTS AND DISCUSSION}

Germination of chickpea seeds was uniform for 6 days under the experimental conditions used. The variation of total nitrogen in the flours during the period was only $5.61 \%$. The non protein nitrogen, $10 \%$ TCA non-precipitable, increased by $120.96 \%$, although this level represented a reduction of only $2.02 \%$ of the protein nitrogen. KHALIL \& MANSUR [ 19] and KHALEQUE et al. [18] reported an increase in protein content after 3 and 4 days germination for chickpea and faba beans, respectively. GANESH KUMAR \& VENKATARAMAN [13] observed a drop of 10 and $17.6 \%$ in total and protein nitrogen and an increase of $50 \%$ in non protein nitrogen in germinated chickpea after $72 \mathrm{hs}$. In relation to the present experiment, the differences could be related to the cultivar characteristics and the conditions of temperature germination adopted by the authors. Variation in Vigna sinensis, Cicer arietinum and Phaseolus aureus storage proteins were
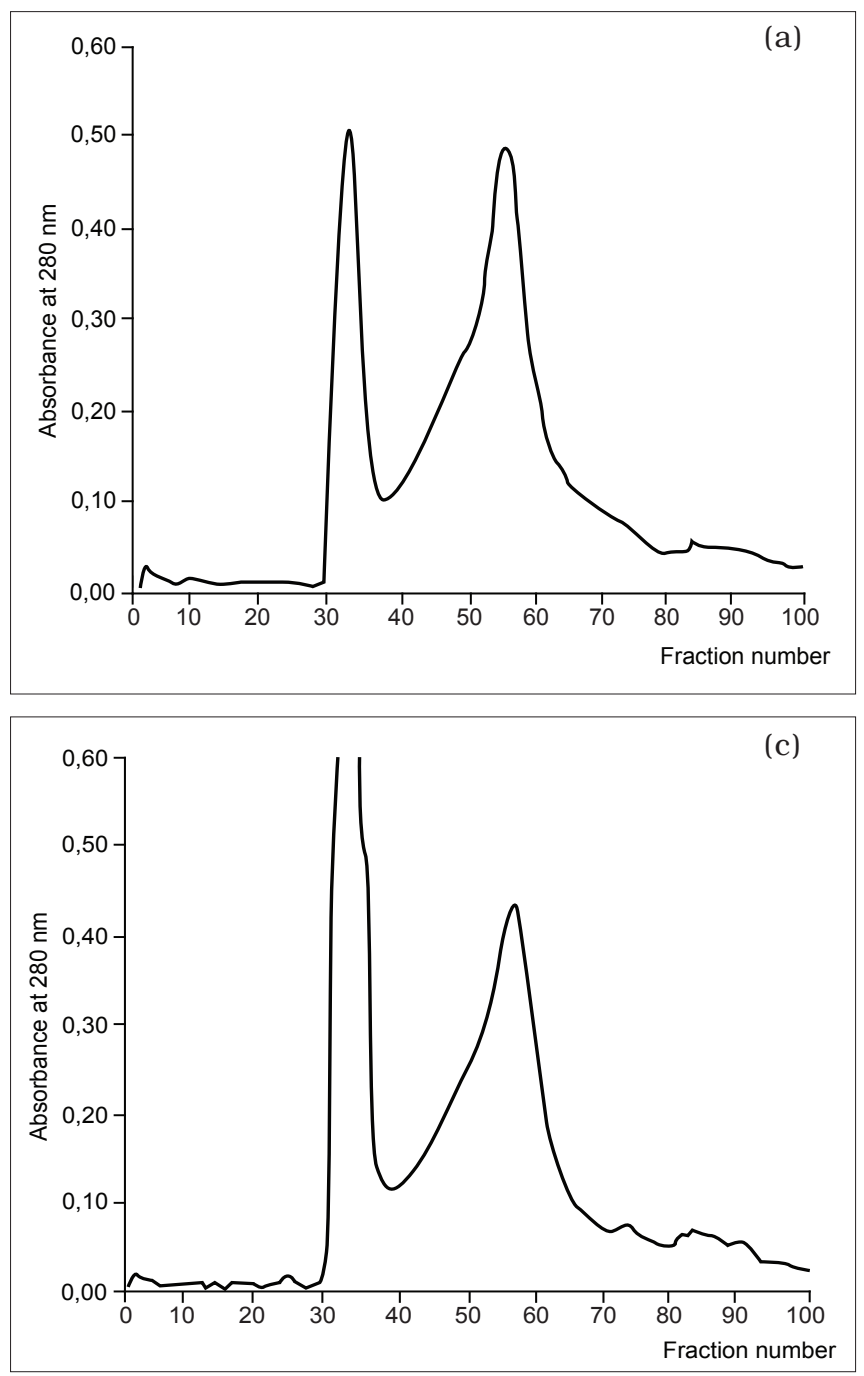

observed during germination but drastic alterations were not observed during a period of 72 hs [13].

The chickpea total globulins corresponded to $45.85 \%$ and $37.08 \%$ of the total seed proteins at the initial and after 6 days of germination, respectively. The albumin fraction was $19.10 \%$ degraded and the dialysable fraction, corresponding to the difference between salt-solubles proteins and the sum of albumin and globulin, increased by $67.95 \%$ during germination of chickpea seeds [25]. Table 1 shows a higher drop in chickpea major globulin between the fourth and sixth day of germination. This alteration at the final

TABLE 1 - Changes in the major globulin of chickpea (vc IACMarrocos) during germination

\begin{tabular}{lcc}
\hline Germination (day) & Protein $^{\mathrm{a}, \mathrm{b}}(\mathbf{m g} / \mathbf{g}$ flour $)$ & \% Reduction \\
\hline 0 & $54.0 \pm 2.3$ & 0 \\
2 & $48.0 \pm 1.8$ & 11.1 \\
4 & $42.0 \pm 2.4$ & 22.2 \\
6 & $21.0 \pm 1.3$ & 61.1 \\
\hline
\end{tabular}

a Determined by the method of Lowry et al. [21] after decorticated/defatted extraction of $5 \mathrm{~g}$ flour as described in Methods; ${ }^{\mathrm{b}}$ Mean values of three replicates
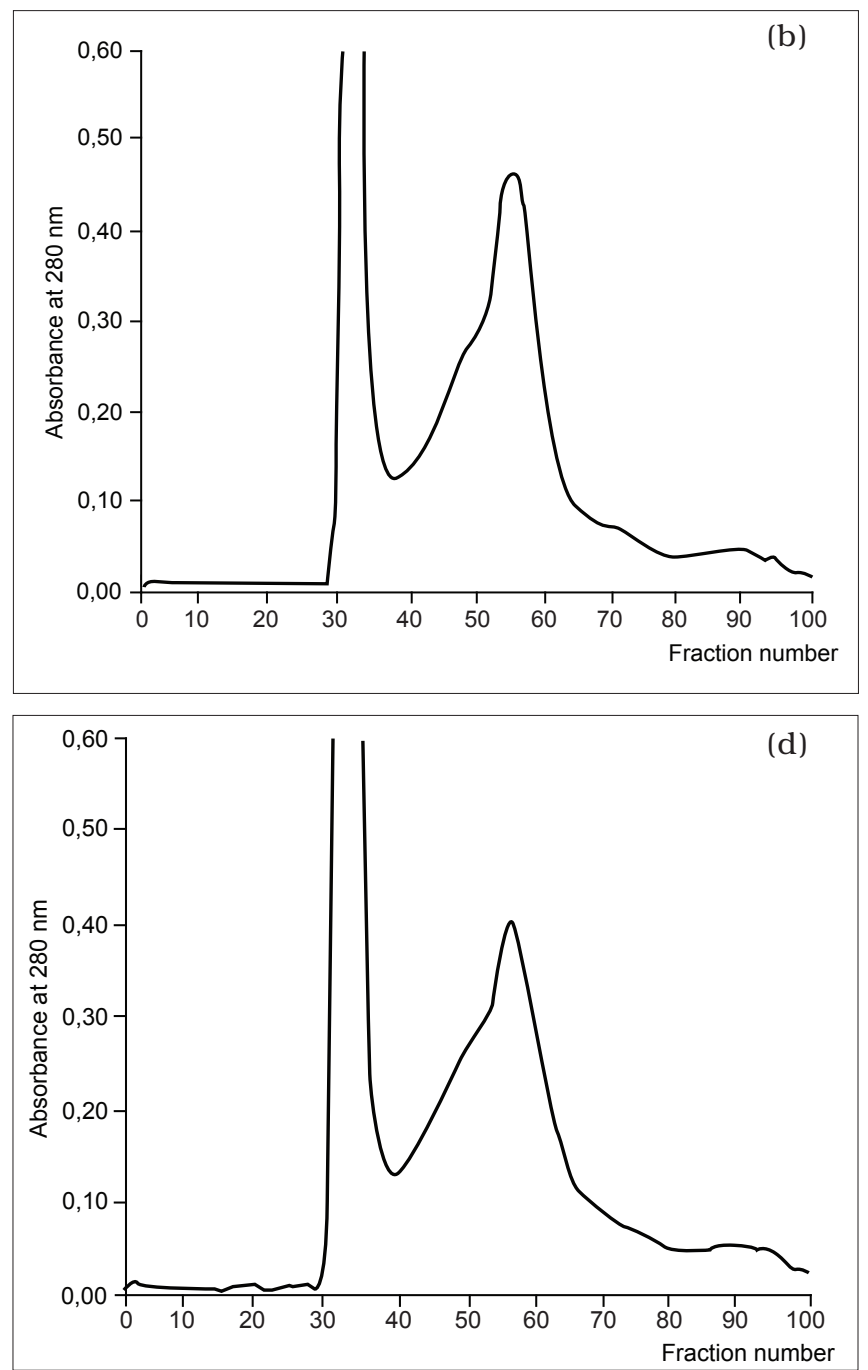

FIGURE 1 - Gel filtration chromatography on Sepharose CL-6B (2.5 X $100 \mathrm{~cm}$ ) of the major (10.3 S) globulin from chickpea. Protein $(44.5 \mathrm{mg}$ ) was applied to the column and fractions of $5.5 \mathrm{ml}$ were collected. A to D: 0 to 6 days germination 
of the germination period had, probably, an effect on the solubility characteristics and consequently on the procedure adopted for protein isolation, since the total globulin showed only a small variation during germination. The alterations after 4 days of germination confirm the results reported by GANESH KUMAR \& VENKATARAMAN [13], which demonstrated extensive protein degradation at the end of the process.

The elution pattern of major globulin of ungerminated seeds through the Sepharose CL-6B gel column (Figure 1) presented two fractions with the first one eluting next to the void volume (Vo). The elution behavior and the distribution of the two fractions showed little modification during germination (Figure 1). Similarly to total globulin [25], the first fraction was very turbid and its absorbance was increased during germination when compared to initial values. However, the major globulin was reduced, presenting a more disperse peak with different elution volumes on the fourth and sixth day of germination, thus indicating the occurrence of a small reduction in the molecular weight of the major globulin fraction. This fact was also observed during germination of another chickpea cultivar under different conditions [14].

SDS-PAGEs of the major globulin in the peak tubes eluted on Sepharose CL-6B (Figure 2) showed the presence of 6 major protein bands with estimated molecular weights of 55, 52.5, 40.2, 38.5, 35.3 and 23 kDa. Furthermore, a weak protein band above $60 \mathrm{kDa}$ may represent undissociated combinations. During germination, the major polypeptides ( 38.5 to $55 \mathrm{kDa}$ ) showed little changes in relative mobility behavior and also in Comassie blue band intensity on the gel. This process was increased at the end of the $6^{\text {th }}$ day and the protein bands between 20 and $30 \mathrm{kDa}$ and above $60 \mathrm{kDa}$ appeared to undergo higher degradation during germination period.

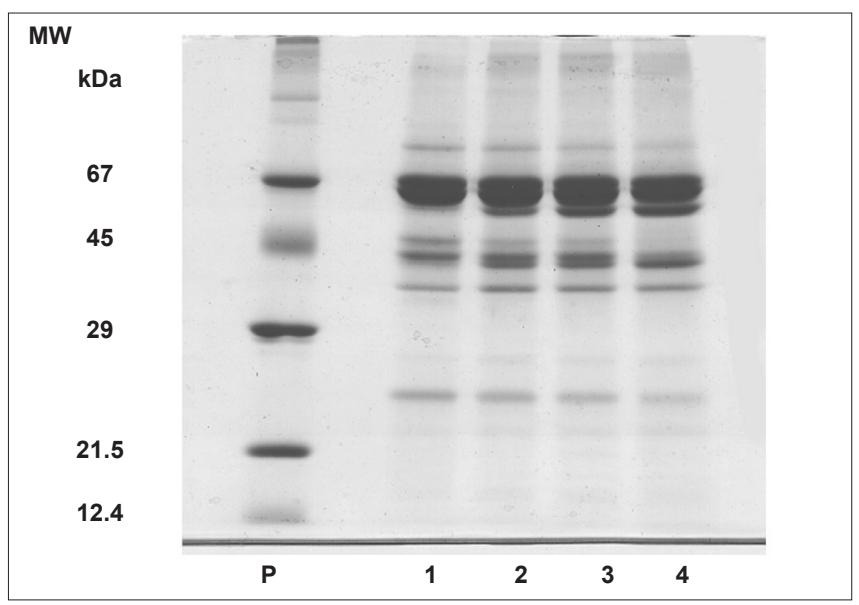

FIGURE 2 - SDS-PAGE of the peaks of major chickpea globulin with maximum absorbance on Sepharose CL-6B chromatography. P: MW markers, 1-4: major globulin at 0, 2, 4 and 6 days germination. Protein load on each gel was fifty $\mu \mathrm{g}$
Using PAGE, several authors observed a reduction in the number of protein bands during the germination of different leguminous seeds as a result of enzymatic degradation [1, 6, 13]. GANESH KUMAR \& VENKATARAMAN [13], using total seed proteins, observed on SDS-PAGE a progressive decrease in the subunit numbers of higher molecular weights and the appearance of smaller ones after 9 days of germination.

The proteolytic activity of the chickpea albumin fraction, using chickpea total globulin and casein as substrates ( 1:5 enzyme:substrate ratio), showed an increase up to the fourth day, followed by a small decrease on the sixth day germination (Table 2). The albumin to globulin ratio in chickpea seeds was 3:5, consequently, the action of the acid proteases may be higher than that obtained in vitro. This increase in proteolytic activity appeared to have been followed by a small decrease in trypsin inhibitor activity during chickpea seed germination, as previously observed in our laboratory [25].

TABLE 2 - Acid protease activitya during chickpea (cv IAC-Marrocos) germination

\begin{tabular}{ccc}
\hline \multirow{2}{*}{ Germination (day) } & \multicolumn{2}{c}{$\mu \mathbf{g}$ amino acid/mg protein ${ }^{\mathrm{b}}$} \\
\cline { 2 - 3 } & Casein & Total chickpea globulin $^{\text {con }}$ \\
\hline 0 & $9.97 \pm 0.34$ & $10.96 \pm 0.42$ \\
2 & $16.16 \pm 0.72$ & $12.32 \pm 0.47$ \\
4 & $23.28 \pm 1.12$ & $19.44 \pm 0.88$ \\
6 & $16.20 \pm 0.65$ & $14.46 \pm 0.76$ \\
\hline
\end{tabular}

a Enzyme source: isolated chickpea albumin fraction; substrate: casein and isolated total chickpea globulin; E:S ratio, 1:5; assayed at pH 5.5 for $4 \mathrm{hs}$; ${ }^{\mathrm{b}}$ the assays were performed in triplicate as described in Methods

The storage protein degradation and the increase in proteolytic activity observed in germinating chickpea seeds are consistent with various reports $[1,4,26]$. The increase in an enzymatic system with caseinolytic activity has been observed during germination of different leguminous species $[4,17$, 26, 27]. Protein degradation during 7 days germination was detected in lentil seeds, accompanied by an increase in the activity of a caseinolytic enzymatic system [4]. $\alpha-\mathrm{N}-$ BenzoylDL-arginine-p-nitroanilide (BAPNA) at $\mathrm{pH} 8.2$ and casein at $\mathrm{pH} 5.5$ were substrates in the enzymatic activity detected during germination of Phaseolus vulgaris. However, the acid protease activity was associated with the disappearance of major globulin (G-1) and represented a thiol protease [26]. After 7 days germination of V.faba, C. arietinum and L. termes, AHMED et al. [1] observed that storage proteins were degraded and enzymes synthesized at different times of germination as a characteristic of the seed.

The present results suggest that the low specificity of the enzymes of the seed to its globulin may indicate that these structural characteristics, associated with proteolytic resistance, represent a subtle mechanism of control of globulin degradation in the germinating process. Chickpea germination causes alterations in the major globulin structure, rendering it more susceptible to enzyme attack, since prior to protease attack the compact structure of the 
globulin needs to be destroyed or altered. These structural changes can be better observed in the chromatographic pattern of the Sepharose CL 6B column (Figure 1) and also in the SDS-PAGE of the peaks of maximum absorbance at $280 \mathrm{~nm}$ in this present experiment (Figure 2).

In general, germination did not modify significantly the in vitro digestibility of the chickpea protein fractions, except for the major globulin that showed an increase to values near to those of casein (Table 3 ). The flour digestibility values showed a small reduction after 6 days germination, a fact that could be related to the variation in the composition of the protein fractions. The albumin fraction showed lower in vitro digestibility, despite the presence of protease inhibitors as constituents of the fraction [25]. Consequently, the albumin and not the globulin fraction appeared to influence the digestibility of chickpea flour. GENOVESE \& LAJOLO [15] verified the influence of the trypsin inhibitors of the albumin fraction in Phaseolus vulgaris on the reduced proteolysis of the phaseolin and casein mixtures. The authors showed the interference of residual trypsin inhibitory activity and temperature with the pepsin-pancreatin digestibility of legume protein fractions.

TABLE 3 - In vitro protein digestibilitya (IVPD) of chickpea flour and isolated protein fractions during seed germination

\begin{tabular}{lcc}
\hline \multicolumn{1}{c}{ Protein $^{\mathbf{b}}$} & INITIAL & 6 $^{\text {th }}$ DAY \\
\hline Chickpea flour & $72.36 \pm 0.95$ & $66.09 \pm 2.96$ \\
Albumin & $51.22 \pm 0.46$ & $51.81 \pm 0.04$ \\
Total globulin & $76.91 \pm 3.16$ & $75.71 \pm 1.65$ \\
Major globulin & $87.57 \pm 1.19$ & $97.49 \pm 0.46$ \\
\hline
\end{tabular}

a Determined by the procedure described by Akeson \& Stahman [3], using the pepsin and pancreatin sequence after incubation at $37^{\circ} \mathrm{C}$ for $3 \mathrm{~h}$ and $24 \mathrm{~h}$, respectively. ${ }^{\text {b }}$ Hammarsten Casein was used as a standard and considered to correspond to $100 \%$ digestibility

KHALEQUE et al. [18] found a decrease in trypsin inhibitor activity and a small increase in the apparent digestibility of chickpea proteins after 4 days germination. DAGNIA, PETTERSON \& FLANAGAN [8] and MOSTAFA \& RHAMA [23] also observed a reduction in trypsin inhibitor activity during 6 days germination in Lupinus angustifolius and soybean seeds, respectively. Nevertheless, only soybean seeds showed increased protein digestibility. In vitro hydrolysis assays using trypsin, chymotrypsin and pepsin revealed that the leguminous storage globulins are less hydrolyzed than casein and that structural aspects of the molecules are factors related to this resistance [2, 10, 24, 27].

\section{4 - CONCLUSIONS}

The proteolytic activity of the chickpea seeds showed an increase up to the fourth day followed by a small decrease on the sixth day germination. This activity was related to albumin fraction and the increase in proteolytic activity was followed by a small decrease in trypsin inhibitor activity during the period of germination. Chickpea germination did not modify significantly the in vitro digestibility of the protein fractions, except for the major globulin that showed an increase to values near to those of casein. The results suggest that the germination causes alterations in the major globulin structure rendering it more susceptible to the enzymes.

\section{5 - LIBRARY REFERENCE}

[1] AHMED, F.A.R.; ABDEL-RALIM, E.A.M.; ABDEL-FATHA, O.M.; ERDMAN V.A.; LIPPMAN, C. The changes of protein patterns during one week of germination of some legume seeds and roots. Food Chem., v. 52, p. 433-437, 1995.

[2] AHN, J.K.; SEN, L.C.; WHITAKER, J.R. Stability of tertiary structure of phaseolin of red kidney bean (Phaseolus vulgaris) as limiting factor in proteolysis. J. Food Biochem., v. 15, p. 263-278, 1991.

[3] AKESON, W.R.; STAHMAN, M.A.A. Pepsin-pancreatin digest index of protein quality evaluation. J. Nutr., v. 83, p. 257-261, 1964.

[4] ALVAREZ, J.; GUERRA, H. Biochemical and morphological changes in protein bodies during germination of lentil seeds. J. Experiml. Botany, v. 36, p. 1296-1303, 1985.

[5] ASSOCIATION OF OFFICIAL ANALYTICAL CHEMISTS. Official Methods of Analysis ( $13^{\text {th }}$ ed.). Washington D.C., 1980.

[6] CHANG, K.C.; HARROLD, R.L. Changes in selected biochemical components, in vitro protein digestibility and amino acids in two bean cultivars during germination. J. Food Sci., v.53, p. 783-804, 1988.

[7] CHAVAN, J.K.; KADAN, S.S.; SALUNKHE, D.K. Biochemistry and technology of chickpea (Cicer arietinum L.) seeds. CRC-Crit. Rev. Food Sci. Nutr., v. 25, p. 107-158, 1988.

[8] DAGNiA, S.G.; PETTERSON, D.S.; FLANAGAN, F.V. Germination alters the chemical composition and protein quality of lupin seeds. J. Sci. Food Agric., v. 60, p. 419-423, 1992.

[9] DERBYSHIRE, E.; WRIGHT, D.J.; BOULTER, D. Legumin and vicilin strorage proteins of legume seeds. Phytochemistry, v. 15, p. 3-24, 1976.

[10] DESHPANDE, S.S.; DAMODARAN, S. Structure digestibility relationship of legume $7 \mathrm{~S}$ protein. J Food Sci.; v. 54, p. 108-113, 1989.

[11] DURANTI, M.; GIUS, C. Legume seeds: protein content and nutritional value. Field Crops Res., v. 53, p. 31-45, 1997.

[12] GANESH KUMAR, K.; VENKTARAMAN, L.V. Changes in reserve proteins of cow pea, chickpea and green gram during germination: Physico-chemical studies. J. Food Sci. Technol., v. 12, p. 292-295, 1995.

[13] GANESH KUMAR, K.; VENKATARAMAN, L.V. Chickpea seed proteins: modification during germination. Phytochemistry, v. 17, p. 605-609, 1978.

[14] GANESH KUMAR, K.; VENKTARAMAN, L. V.; APPU RAO, A.G. Chickpea seed proteins: conformational changes in $10.3 \mathrm{~S}$ protein during germination. J. Agric. Food Chem., v. 28, p. 518-524, 1980.

[15] GENOVESE, M.I.; LAJOLO, F.M. Effect of bean (Phaseolus vulgaris L.) albumins on phaseolin in vitro digestibility, role of trypsin inhibitors. J. Food Biochem., v. 20, p. 275-294, 1996.

[16] GENOVESE, M.I.; LAJOLO, F.M. Influence of naturally acid-soluble proteins form beans (Phaseolus vulgaris 
L.) on in vitro digestibility determination. Food Chem., v. 62 , p. $315-323,1998$.

[17] GUERRA, H.; NICOLÁS, G. Changes in nitrogen fraction and proteolytic activities in the cotyledons of germinating lentils. Rev. Espan. Fisiol., v. 39, p. 277- 282, 1983.

[18] KHALEQUE, A.; ELIAS, L.G.; BRABAM, J. E.; BRESSANI, R. Studies on the development of infant foods from plant protein sources. Part I - Effect of germination of chickpea (Cicer arietinum L.) on the nutritive value and digestibility of proteins. Arch. Latinoamer. Nutr., v. 35, p. 315-325, 1985.

[19] KHALIL, A.H.; MANSOUR, E.H. The effect of cooking, autoclaving and germination on the nutritional quality of faba beans. Food Chem., v. 54, p. 177-82, 1995.

[20] LAEMLLI, U.K. Cleavage of structural proteins during assembly of the head of bacteriophage T4. Nature, v. 227, p. 680-684, 1970.

[21] LOWRY, O.H.; ROSEBROUGH, N.J.; FARR, A.L.; RANDALL, R.J. Protein measurement with the Folin phenol reagent. J. Biol. Chem., v. 193, p. 265-75, 1951.

[22] MANSOUR, E.H. Biological and chemical evaluation of chickpea seed proteins as affected by germination, extraction and $\alpha$-amilase treatment. Plant Foods Hum. Nutr., v. 49, p. 271-282, 1996.

[23] MOSTAFA, M.M.; RHAMA, E.H. Chemical and nutritional changes in soybean during germination. Food Chem., v. 23, p. 257-275, 1987.

[24] NEVES, V.A.; LOURENÇO, E.J. Isolation and in vitro hydrolysis of globulin G.1 from lentils (Lens culinaris Medik.). J. Food Biochem., v. 19, p. 109-120, 1995.

[25] NEVES, V.A.; LOURENÇO, E.J. Changes in protein fractions, trypsin inhibitor and proteolytic activity in the cotyledons of germinating chickpea. Arch. Lati- noamer. Nutr., v. 51, p. 269-275, 2001.

[26] NIELSEN, S.S.; LIENER, I.E. Degradation of major storage protein of Phaseolus vulgaris during germination. Plant Physiol., v. 74, p. 494- 498, 1984.

[27] NIELSEN, S.S.; DESHPANDE, S.S.; HERMODSON, M.A.; SCOTT, M.P. Comparative digestibility of legume storage proteins. J. Agric. Food Chem., v. 36, p. 896-902, 1988.

[28] SATHE, S.K.; SALUNKHE, D.K. Solubilization and electrophoretic characterization of the great northern bean (Phaseolus vulgaris L.) proteins. J. Food Sci.., v. 46, p. 82-87, 1981.

[29] SATHE, S.K.; DESHPANDE, S.S.; REDDY, N.R.; GOLL, D.E.; SALUNKHE, D.K. Effect of germination on protein, raffinose oligosaccharides and antinutritional factors in the Great northern bean (Phaseolus vulgaris $L$.). J. Food Sci., v. 48, p. 1796-1800, 1983.

[30] SPADARO, A.C.C.; DRAGHETTA, W.; DEL LAMA, S.N.; CAMARGO, A.C.M.; GREENE, L.T. A convenient manual trinitrobenzenesulphonic acid method for monitoring amino acids and peptides in chromatography effluents. Anal. Biochem., v. 96, p. 317-321, 1979.

[31] SUDESH JOOD, B.M.; CHAUHAN, V.; KAPOOR, A.C. Protein digestibility (in vitro) of chickpea and black gram seeds as affected by domestic processing and cooking. Plant Foods Human Nutr., v. 39, p. 149154, 1989.

\section{6 - ACKNOWLEDGEMENT}

The authors are grateful to Instituto Agronômico de Campinas (IAC) for the chickpea samples and to the Research Commission Program of the Faculty of Pharmaceutical Sciences-UNESP (PADC-FCF-UNESP) and CNPq-PIBIC Program for financial support. 